ESPAÇO IMAGEM

IMAGING Space

Responsável: Manoel Barros Bértolo

\title{
Pseudo Podagra em uma Paciente com Artrite Reumatóide (AR): Doença do Pedicuro?
}

\section{Pseudo Podagra in a Rheumatoid Arthritis (RA) Patient: Pedicure Disease?}

\author{
Breno Schor ${ }^{(1)}$, Morton A. Scheinberg ${ }^{(1)}$, Jorge Ronald Spitz ${ }^{(2)}$
}

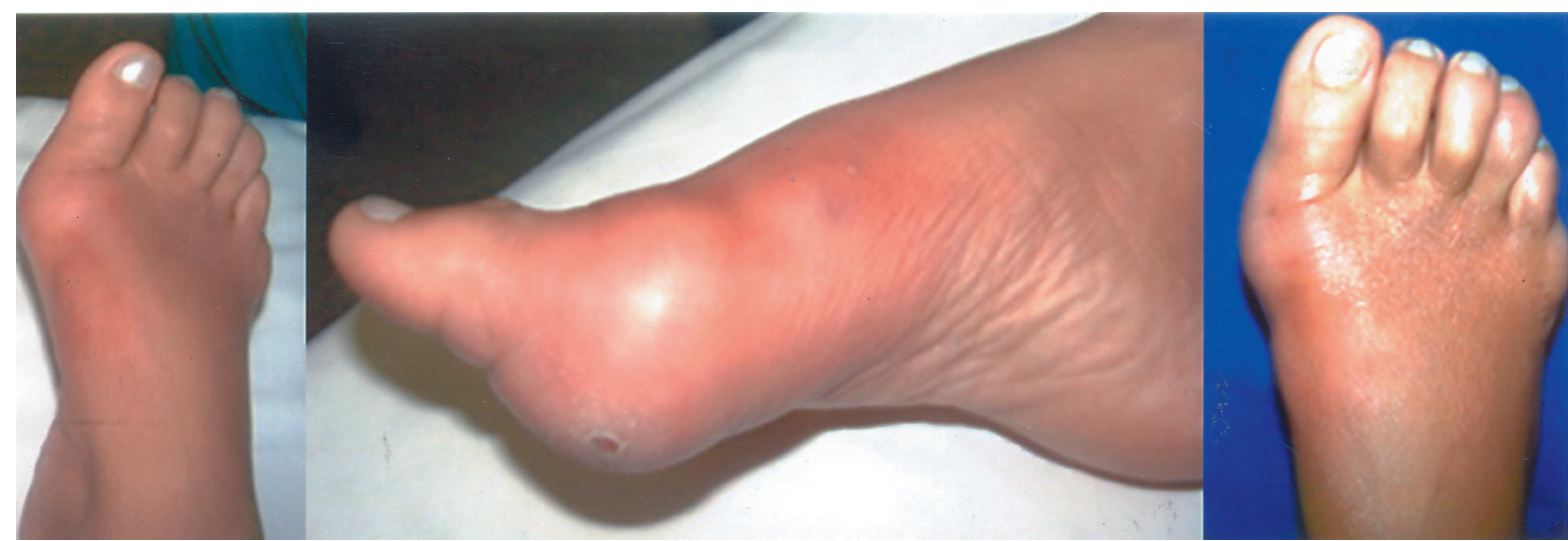

Figura 1 - Articulação com aumento de volume antes e após drenagem do abscesso periarticular

Uma paciente do sexo feminino foi diagnosticada com artrite reumatóide (AR) há aproximadamente um ano. Após três meses de uso de antiinflamatórios passou a receber $10 \mathrm{mg}$ de metotrexato, semanalmente, e entrou em remissão clínica. Ela foi vista seis meses depois no Serviço de pronto atendimento do Hospital Israelita Albert Einstein, em São Paulo, com uma história aguda de dor e inchaço na primeira articulação metatarsofalangiana (Figura 1). Três dias antes, ela foi atendida no exterior (Londres), por um clínico que suspeitou de infecção local e iniciou eritromicina por via oral. Não houve melhora clínica e o diagnóstico de abscesso periarticular foi feito com subseqüente drenagem em centro cirúrgico. As culturas foram positivas para $S$. aureus, que no antibiograma mostrou ser resistente à eritromicina e sensível a ciprofloxacino. Ela foi referida ao clínico-reumatologista para seguimento posterior (J.R.S.), na cidade do Rio de Janeiro, onde reside. Embora o uso de imunossupressores possa ter facilitado o aparecimento da infecção, ela já não usava metotrexato semanal há um bom tempo. Duas semanas antes de viajar ao exterior, ela teve um atendimento com o pedicuro para tratamento rotineiro das unhas. Acreditamos que, na ocasião, deva ter ocorrido a porta de entrada do quadro infeccioso.

1. Hospital Israelita Albert Einstein, Instituto de Ensino e Pesquisa, São Paulo/SP, Brasil

2. Hospital Samaritano, Clínica Médica, Rio de Janeiro/RJ, Brasil 